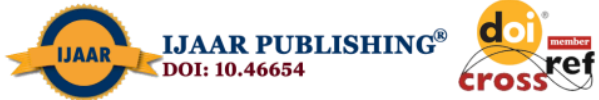

International Journal of Advanced Academic Research (Business and Economic Development) | ISSN: 2488-9849

Journal DOI: 10.46654/ij.24889849

Vol. 6, Issue 11 (November, 2020)|www.ijaar.org

Article DOI: 10.46654/ij.24889849.b61122

\section{BRANDING AND CONSUMER BEHAVIOUR OF SELECTED PETROLEUM PRODUCTS IN PORT HARCOURT, RIVERS STATE}

\author{
Akor John Abah \\ Doctoral student, \\ Department of Management, \\ University of Port Harcourt, Rivers State, Nigeria. \\ Email: johnakor93@gmail.com \\ Benedict Chima Onuoha, Ph.D \\ Professor of Management, \\ University of Port Harcourt, Rivers State, Nigeria. \\ Email: chimaonuoha2005@yahoo.com
}

\begin{abstract}
Consumer behavior to branding is a serious issue that affects owners of businesses. This study addresses the challenges as determinants of customer impulse buying behavior of consumers of petroleum product in Rivers State, Nigeria. The study employed a descriptive survey design to examine 550 consumers of petroleum products in Rivers State. The sample size determination for a finite population as expressed by Krejie and Morgan (1970) and used by Research advisors (2006) was used to draw a sample of 550 consumers of petroleum products. Proportionate sample technique (a variant of stratified sampling method) to reflect the proportions of consumers in each of the 23 local government areas of the state. A research questionnaire was constructed, validated and administered to obtain the primary data. The factor analysis simple regression analysis and Pearson product moment correlation( $r$ ) statistical techniques were used to test the hypotheses. The findings of the study revealed that there is significant relationship between branding and consumer behavior $\left(P<0.05, R=0.786, R^{2}=0.618\right)$. It was concluded that high levels of awareness positively influence the choice of petroleum products by consumers. The study therefore recommends that marketers of petroleum products should develop innovative packaging strategies that will appeal to and attract consumers in an exceptional way to trigger impulse buying.
\end{abstract}

Keywords: Branding, Consumer Behaviour 


\subsection{Background to the study}

The liberalization of the petroleum products in Nigeria has led to stiff competition in the once oligopolistic market structure. The country now boasts of more licensed players and more still picking interest in the market (Alexander, 2008). The increased level of competition has prompted fuel dealers to start building on all those fundamentals that can give them competitive edge in this growing market. Companies have embarked on engaging in price wars and building brand images in way of influencing consumer behaviours (Alexander, 2008).

Brand image is the current view of the customers about a brand. It is a unique bundle of associations within the minds of target customers and signifies what the brand presently stands for (Dwayne, 2005). It is a set of beliefs held about a specific brand, that is to say, it is nothing but the consumers' perception about the products. It is the manner in which a specific brand is positioned in the market, which does not only convey mental images but also emotional value. According to Grewal, Krishna, Baker and Borm (1998), the better a brand image is, the more recognition consumers give to its product quality.

According to Dixon (2005), people engaged in consumption do not merely buy certain products to satisfy basic needs. In fact, consumer buying habits are at a much deeper level. Owning a certain brand can help consumers to express and build their own self-concept. Specifically, consumers will only purchase certain trademark when they find a match between the brand image (communicated through advertisement, design of retail shop, or even package design) and his/her own self-concept. The value of a brand therefore also depends on its ability to help consumer to build and create self-concept.

Aaker (1991) believes brand establishment and management should not only be one of the operating focuses for major industries but viewed as a source of competitiveness. For consumers, a brand provides a certain degree of product guarantee. Shopping around can be time- and energy-consuming and consumers do not always possess enough product knowledge to ensure the best buy. Under such circumstances, consumers usually go by well-known brands, which may result in higher cost but requires less research efforts, thus, branding does not only affect how consumers view a product but also has the benefit of lowering purchase risks (Loudon $\&$ Bitta, 1998).

According to Kotler (2000), consumer behaviour occurs when consumers are stimulated by external factors and come to a purchase decision based on their personal characteristics and decision making process. Through branding consumers are able to recognize a product, evaluate the quality, lower purchase risks and obtain certain experience and satisfaction out of product differentiation.

\section{Statement of the problem}

The liberalization of the petroleum product in Nigeria has increased competition and worsened the fight for consumers making survival difficult. Many small players have joined the market, worsening the already competitive market structure. However, despite this influx and the continuous efforts by the small petroleum companies to engage in all activities that make them took more favourable and economical in the eyes of the customers, market share statistics have 
continuously showed that big names like NNPC and Total are still preferred by consumers. Thus, the failure by many petroleum companies to understand the relevance of building a strong brand image has made their survival difficult.

People in our society are so conscious about their status and they prefer to use branded products to show off their status symbol brand is considered as implied device through which any business can attain the attraction of people and can enjoy the competitive edge. In our local scenario, it is considered as a valuable asset for any business as it can change people's buying behaviour. The study intends to assess the effect of branding on consumer behaviour of selected petroleum products in Cross River State.

\section{Objectives of the study}

The general objective of the study is to examine the effect of branding on consumer behaviour of selected petroleum products.

The specific objectives are:

1. To examine the impact of reduced branding on consumer behaviour.

2. To examine the impact of increased non-branded information on consumer choice.

3. To determine the effect of copycat branding on consumer behaviour.

4. To ascertain the effect of branding on consumer perception bias.

\section{Research questions}

The formulated questions are based on the objective of the study:

1. How does reduced branding affect consumer behaviour?

2. What is the impact of increased non-branded information on consumer choice?

3. What is the effect of copycat branding on consumer behaviour?

4. To what extent does branding affect consumer perception bias?

\section{Research hypotheses}

The hypotheses are formulated in null form

$\mathbf{H}_{\mathbf{0}}$ 1: There is no significant relationship between reduced branding and consumer behaviour.

$\mathbf{H}_{\mathbf{0}}$ 2: There is no significant relationship between non-branding information and consumer choice.

Ho3: There is no significant relationship between copycat branding and consumer behaviour.

$\mathbf{H}_{\mathbf{0}} 4$ : There is no significant relationship between branding and consumer perception bias.

\section{Significance of the study}

The study will be beneficial to the following groups:

1. The study will be beneficial to researchers by adding to existing knowledge.

2. The study will be of immense benefit to petroleum companies. 
3. The study will be of immense benefit to academic community, further researchers, other organizations including policy makers.

\section{Assumptions of the study}

The following assumptions of the study are made:

(i) The variables in this study are generalizable.

(ii) The methodology is appropriate.

(iii) Better branding gives product quality to consumers.

(iv) The findings of the study are replicable.

\section{Scope and limitation of the study}

Geographically, the study is limited to River State. Much as the researcher intends to study two selected petroleum companies all the retail outlets (stations) that were included in the study, were selected randomly from River State.

Contentwise, the researcher investigates on branding, its connection with consumer behaviour and their effect on consumer behaviour. The limitations of the study are: Lack of adequate materials, false information from the respondents, lack of data, time constraint, finance constraint and the study area.

\section{Historical background of the study}

\section{(a) Total petroleum}

Total's history began in the 1920s, with the creation of Compagine Francaise des Petroles (CFP). Total Nigeria Plc, formerly known as Total Fina EIF Nigeria Plc, is the entity which emerged following the successful merger between Total Nigeria Plc and EIF Oil Nigeria Ltd. on 11th September, 2001.

Total Nigeria Plc was corporate as a marketing product in Nigeria. The company is a marketing and services subsidiary of Total for over fifty years. Total Nigeria Plc main business is distribution and marketing of refined petroleum products and fuels. The company has petrol diesel, kerosene, aviation fuel, liquefied petroleum, etc.

\section{(b) NNPC}

The Nigerian National Petroleum Corporation (NNPC) is the state oil corporation through which the Federal Government of Nigerian regulates and participates in the country's petroleum industry. NNPC was established on April 1, 1977 as a merger of the Nigerian National Oil Corporation and the Federal Ministry of Mines and Steel. NNPC by law manages the joint venture between the Nigerian Federal Government and a number of foreign multinational corporations, which include Royal Dutch Shell, Exxon Mobil, Chevron and Texaco (now merged with Chevron) through collaboration with these companies, the Nigerian government conduct petroleum exploration and production. In 2007, the head of the Nigeria Wing of Transparency International paid salaries for NNPC workers were too low to prevent graft. 
The NNPC Towers in Abuja is the headquarters of NNPC consisting of four identical towers; the complex is located on Herbert Macaulay Way, Central Business District, Abuja. NNPC also has zonal offices in Lagos, Kaduna, Port Harcourt and Warri. It has an international office located in London and United Kingdom.

\section{Definition of terms}

The following terminologies are operationally defined:

(1) Brand: It is a product, service or concept that is publicly distinguished from others. It is expressed in the form of graphic representation of the brand.

(2) Branding: The process involved in creating a unique name and image for a product.

(3) Consumer behaviour: It is the behaviour that consumer displays in searching for, purchasing using, evaluating and disposing of products and services that they expect will satisfy their services and needs.

(4) Consumer products: It is any tangible product for sale that is used by a person or household for non-business purposes.

(5) Petroleum products: Are useful materials derived from crude oil as it is processed in oil refineries. Petroleum products are obtained from crude oil and natural gas processing, including automotive gasolines, aviation gasoline, fuel, oils, kerosene, etc.

\subsection{LITERATURE REVIEW AND THEORETICAL FRAMEWORK}

There are many theories relating to the brand and branding such as:

\section{Theory brand loyalty}

This theory was propounded by Jagdish and Whan (1974), the theory of brand loyalty explains the relationship of customer's psychology with the brand of a company. According to this theory, the positive behaviour of a customer towards a brand has three different aspects. Emotional attachment, brand evaluation and behavioural aspect. The first aspect relates to the emotional attachment of customer with the brand. That is, how much he/she likes or dislikes a product. If this is positive, the consumer will always be inclined to buy this product.

\section{The branding theory}

This theory was propounded by Lazarsfeld (1970), this theory provides guidance on some important typical components of brand including:

(a) The assignment of a specific name to the brand which can portray the business.

(b) Then making the people aware of this brand.

(c) Try to provide what they want.

(d) Establish a relationship with your very first customer and then keep on growing.

(e) And try to reach the top with no compromise in any function of brand development. 


\section{The value-based brand theory}

This theory was propounded by Keller (2003), this theory explains that the value-based brands are intended to build long term customer value. The success all depends upon the value which the brand delivers to the customers. The value-based brand theory argues that the customer is the supreme spirited contrivance to defeat the competitors, it says a brand's like blood is the customer.

\section{Concept of brand and branding}

A brand is a product, service or concept that is publicly distinguished from other products, services, or concepts so that it can be easily communicated and usually marketed. A brand name is the name of the distinctive product, service or concept. Branding is the process of creating and disseminating the brand name. Branding can be applied to the entire corporate identity as well as to individual product and service names (Aaker, 1991:30).

Brands are usually protected from use by others by securing a trademark or service mark from an unauthorized agency, usually a government agency. Before applying for a trademark or service mark, you need to establish that someone else hasn't already obtained one for your name. Although you can do the searching yourself, it is common to hire a law firm that specializes in doing trademark searches and managing the application process, which, in the United States, takes about a year. Once you have learned that no one else is using it, you can begin to use your brand name as a trademark simply by stating it is a trademark (Aaker and Founiew \& Brasel, 2004:4).

Brands are often expressed in the form of logos, graphic representations of the brand, etc. In computers, a recent example of widespread brand application was the "Intel inside" label provided to manufacturers that use Intel's microchips. A company's brands and the public's awareness of them is often used as a factor in evaluating a company (Arnold, 2007:90).

Proper branding can result in higher sales of not only one product, but on other products associated with that brand. Some people distinguish the psychological aspects, brand associations like thought, feelings, perceptions, images, experiences, beliefs, attitudes and so on that became linked to the brand, of a brand from the experiential aspect. The experiential aspect consists of the sum of all parts of contact with the brand and is known as the brand experience (Botton, Warlop \& Alba, 2003:40).

\section{Characteristics of a good brand name}

There are characteristics of a good brand name (Arnold, 2007:17):

1. It should be distinctive: The market is filled with over-worked names and over-used symbols. A unique and distinctive symbol is not only easy to remember but also a distinguishing feature.

2. It should be suggestive: A well-chosen name or symbol should be suggestive of quality or may be associated with superiority or a great personality.

3. It should be appropriate: Many products are surrounded by a certain mystique in the minds of the customers. Carefree is an appropriate brand name of a sanitary towel. 
4. It should be easy to remember: It should be easy to read, pronounce and spell.

5. It should be adaptable to new products.

\section{Branding policies}

There are policies of branding which lead to business success (Arnold, 2007:25):

(a) Define your brand: It starts with your authenticity the core purpose, vision, mission, position, values and character.

(b) Your brand is your business model: Supports and challenge your business model to maximize the potential within your rand.

(c) Consistency: Consistency in your message is the key to differentiate.

(d) Start from the inside out: Everyone in your company can tell you what they see, think and feel about your brand. That's the story you should bring to the customers as well, drive impact beyond just the walls of marketing.

(e) Connect on the emotional level: A brand is not a name, logo, website and campaigns. A brand is a desirable idea manifested in products, services, people and experiences.

(f) Empower brand champions: Award those that love your brand to help drive the message, facility activities so that they can be part of the process.

(g) Stay relevant and flexible: A well managed brand is always making adjustments. Branding is the process, not a race, not an event so expect to constantly tweak your message and refresh your image. Successful brands don't cling to the old ways just because they worked in the past; instead, they try to reinvent themselves by being flexible which frees them to be more savvy and creative.

(h) Align tactics with strategy: Convey the brand message on the most appropriate media platform with specific campaign objectives. Because consumers are bombarded by commercial messages every day, they are also actively blocking out the great majority of them.

(i) Measure the effectiveness: Focus on the return on investment is the key to measure the effectiveness of your strategies. Ultimately it should resonate with sales and that means of profitability. But don't just focus increasing sales when you could be getting profit boost by reducing overheads and expenses as well.

(j) Cultivate your community: Community is a powerful and effective platform on which to engage customers and create loyalty towards the brand. In an active community, members feel a need to connect with each other in the context of the brand's consumption.

(k) Keep your enemies closer: Even if you have the most innovative, highly desirable product, you can expect new competitors with a superior value proposition to enter your market down the road.

(1) Practice brand strategy thinking: This concept actually applies to your brand strategy creation process. It is always easier to execute tactics than coming up with a strategy because it implies the possibility of failure in brands. 


\section{Importance of branding}

Company branding is the most efficient way to show potential customers what your business is about. It is reflected visually via the logo and company design elements as well as through verbiage in marketing materials, slogans and information copy. The brand is a promise of the value you receive (Cove \& Remy, 2007:17):

\section{- Uniqueness}

Utilize your branding to set yourself apart from competitors. To do this, analyze what you do best and consider you target demographic use graphics and word choices that clearly reflect your business to your target audience, hence your brand.

- $\quad$ Target audience

Your band can assist you in getting a stronger foothold in your niche market. Define your unique selling position and consider methods to communicate key messages to your desired audience. Use specific images or phrases to encourage the fee of inclusivity.

- $\quad$ Emotional connections

According to Arnold (2007:10), the power of branding has successfully melded into that of personal identification and emotional connection.

- $\quad$ Message delivery

Having strong branding can evoke trust from your niche market. This can translate to your newsletters, emails and advertisements garnering a greater response, hence increasing sales. As people will already be vested in your brand, they will be confident that they will receive value for time spent reading your messages or researching your product.

\section{- $\quad$ Consistency}

Focus on your long-term branding efforts to keep your business consistent. This consistency should transcend messages, product lines and audience appeal. It should enhance your business, adding depth to your company's presence. This should allow you to grow and keep a loyal following.

\section{Advantages and disadvantages of branding}

According to Fraji and Martinez (2007:26), when a company looks to establish itself in the market place, it often turns to branding to help. The concept of branding and identity is to create a look and feel immediately identifiable and recognizable in the market place. Good branding can increase the value of the product and the company itself. A company's identity in the market place can easily make or break its profitability as a whole.

\section{- $\quad$ Awareness}

The harder a company work, on its branding and identity, in most cases, the more awareness it creates. A consumer can seen it in a foreign country, with labelling in a foreign language. 
- $\quad$ Consistency in the market place

The more often a customer sees your brand in the market place, the more often he will consider it for purchase. If the brand and identity are truly kept consistent, the customer is more likely to feel that the quality is consistent and to become a loyal follower of the brand. However, this means that the product must maintain a consistency that reflects image as well.

\section{Disadvantages of branding}

1. Many brands strive to be No.1 in the minds of consumers.

2. Negative attitudes

If a product or service experiences a negative event, that will become attached to the brand. For example a massive recall or unintentionally offensive advertisement campaign can tarnish a company's brand and image, causing the company to need to build a whole new brand and identity to recapture its place in the market.

\section{Consumer behaviour}

Consumer behaviour is the study of individuals, groups or organizations and the processes they use to select, secure, use and dispose of products, services experiences, or ideas to satisfy needs and the impacts that these processes have on the consumer and society. It blends elements from psychology, sociology, social anthropology, marketing and economics. It attempts to understand the decision-making processes of buyers, both individual and in groups such as how emotions affect buying behaviour. It studied characteristics of individual consumers such as demographics and behavioural variables in an attempt to understand people's wants. It also tries to assess influences on the consumer from groups such as family, friends, sports, reference groups and society in general (Hatch \& Schultz, 2003:12).

Customer behaviour study is based on consumer buying behaviour, with the customer playing the three distinct roles of user, payer and buyer. Research has shown that consumer behaviour is difficult to predict, even for experts in the field. Relationship marketing is an influential asset for customer behaviour analysis as it has a keen interest in the rediscovery of the true meaning of marketing through the reaffirmation of the importance of the customer or buyer. A greater importance is also placed on consumer retention, customer relationship management, personalization, customization and one-to-one marketing. Social functions can be categorized into social choice and welfare functions (Kapferer, 2004:17).

\section{Concept of consumer behaviour}

Consumer behaviour is the study of individuals, groups, or organizations and the processes they use to select, secure, use and dispose of products, services, experience, or ideas to satisfy needs and the impacts that these processes have on the consumer and society. It blends elements from psychology, sociology, social enthropology, marketing and economies. It attempts to understand the decision-making processes of buyers, both individually and in groups such as how emotions affect buying behaviour. It studies characteristic of individual consumers such as demographics and behavioural variables in an attempt to understand people's wants. It also tries to assess influences on the consumer from groups such as family, friends, sports, reference groups and society in general. 
Consumer behaviour study is based on consumer buying behaviour, with the customer playing the three distinct roles of uses, payer and buyer. Research has shown that consumer behaviour is difficult to predict, even for experts in the field. Relationship marketing is an influential asset for customer behaviour analysis as it has a keen interest in the re-discovery of the true meaning of marketing through the re-affirmation of the importance of the customer or buyer.

\section{Factors that affect consumer behaviour}

There are four main types or factors influencing consumer behaviour: Cultural factors social factors, personal factors and psychological factors.

\section{(i) Cultural factors}

Cultural factors are coming from the different components related to culture or cultural environment from which the consumer belongs.

- $\quad$ Culture and societal environment

Culture is crucial when it comes to understanding the needs and behaviours of an individual. Throughout his existence, an individual will be influenced by his family, his friends, his cultural environment or society that will "teach" him values, preferences as well as common behaviours to their own culture (Kotler, 1991:25).

For a brand, it is important to understand and take into account the cultural factors inherent to each market or to each situation in order to adapt its product and its marketing strategy.

- $\quad$ Social classes

These are defined as group more or less homogenous and ranked against each other according to a form of social hierarchy.

\section{(ii) Social factors}

Social factors are among the factors influencing consumer behaviour significantly. They fall into three categories: reference groups, family and social roles and status.

- $\quad$ Reference groups and membership groups

The membership groups of an individual are social groups to which he belongs and which will influence him. The membership groups are usually related to its social origin, age, place of residence, work, hobbies, etc.

Family

The family is, maybe the most influencing factor for an individual. It forms an environment of socialization in which an individual will evolve, shape his personality and acquire values. 


\section{(iii) Personal factors}

Decisions and buying behaviour are obviously also influenced by the characteristics of each consumer.

- $\quad$ Age and way life A consume does not buy the same products or services at 20 or 70 years. His lifestyle, values, environment, activities, hobbies and consumer habits evolve throughout his life.

- $\quad$ Purchasing power and revenue

The purchasing power of an individual will have, or course, a decisive influence on his behaviour and purchasing decision based on his income and his capital.

- $\quad$ Lifestyle

The lifestyle of an individual includes all of its activities, interests, values and opinions.

(iv) Psychological factors

Among the factors influencing consumer behaviour, psychological factors can be divided into four categories: Motivation, perception, learning as well as beliefs and attitudes.

- Motivation

Motivation is what will drive consumers to develop a purchasing behaviour. It is the expression of a need in which became pressing enough to lead the consumer to want to satisfy it. It is usually working at a subconscious level and is often difficult to measure.

- $\quad$ Perception

It is the process through which an individual selects, organizes and interprets the information he receives in order to do something that makes sense. The perception of a situation at a given time may decide if and how the person will act.

- $\quad$ Learning

Learning is through action: When we act, we learn. It implies a change in the behaviour resulting from the experience. The learning changes the behaviour of an individual as he acquires information and experience.

- $\quad$ Beliefs and attitudes

A belief is a conviction that an individual has on something. Through the experience he acquires, his learning and his eternal influences while an attitude can be defined as a feeling, an assessment of an object or idea and the predisposition to act in a certain way toward the object. Attitudes allow the individual to develop coherent behaviour against a class of similar objectives or ideas.

\section{Consumer products}

Consumer products companies are looking to maximize profits and market share in an interconnected, competitive environment. For challenges for these organizations include meeting 
the changes demands of customers, maneuvering through a consolidating market and executing strategies to grow profitably (Leitch \& Richardson, 2003:17).

It is an article, or component part produced or distributed: (i) for sale to a consumer for se in or around a permanent or temporary household or residence, a school, in recreation or otherwise; (ii) for the personal use, consumption or enjoyment of a consumer in or around a permanent or temporary household. Any article which is not customarily produced or distributed for sale, or use or consumption by, or enjoyment of a consumer ( $\mathrm{Li}, 2009: 14)$.

Consumer product is any tangible product for sale that is used by a person or household for non-business purposes, consumer products are defined on a case-by-case, under guidelines defined by us. The production and sale of consumer products is an important component of GDP and employment.

\section{Petroleum products industry in Rivers State}

Rivers State is one of the Southern States of the Federation of Nigeria. Petroleum products in Rivers State are distributed to many consumers both public and private organizations. Petroleum products are supplied to banks, offices, hotels, etc.

These products comprise of oil, petrol, fuel, kerosene. Petroleum products industry in Cross River State venture industry in distributing their products either in wholesale or retail. The oil sector in Rivers State has contributed to the growth and development of our State. The consumers of petroleum products are concerned with the process and activities of how distributors of these products operate. Rivers State does not produce petroleum products rather seen as marketers, distributors, wholesalers or retailers, etc.

Furthermore, for example in Rivers State, there are any dealers of petroleum products in all the Local Government of Rivers State. Port Harcourt which is the Capital, has many petrol stations and these stations are involved in many products such as kerosene, oil, petrol or fuel, engine oil and others. Petroleum products industry affects the lives of individuals and society at large.

\subsection{Research design}

A research design is a plan, strategy where a research is either asking question about what is or why it is. In order to answer such questions, a researcher needs to investigate the relationship between independent and dependent variables.

The study employs survey design which requires the use of questionnaire to collect data that will enable the researcher draw conclusion on the effect of branding on consumer behaviour of selected petroleum products in Rivers State

\section{Study area}

The study focuses on the effect of branding on consumer behaviour of selected petroleum products in Rivers State, a study of NNPC and Total Petrol Stations in Port Harcourt. The emphasis was laid on customers. Port Harcourt is a city in Rivers State and it is the State capital. 
Journal DOI: 10.46654/ij.24889849

Vol. 6, Issue 11 (November, 2020) | www.ijaar.org

Article DOI: 10.46654/ij.24889849.b61122

\section{Population of the study}

The population of the study comprises five hundred and fifty (550) customers who patronize petroleum products in Rivers State.

\section{Sampling procedure and sample size determination}

Taro Yamane formular is used to select sample since the information will be collected from firms. It is important to use Taro Yamane formular to avoid bias.

The Taro's formular is expressed thus:

$$
\mathrm{n}=\frac{\mathrm{n}}{1+\mathrm{N}(\mathrm{e})^{2}}
$$

Where;

$$
\begin{aligned}
& \mathrm{n}=\text { sample size } \\
& \mathrm{N}=\text { population size } \\
& \text { e }=\text { tolerable error } \\
& 1=\text { constant } \\
& \mathrm{n}=\frac{550}{1+550(0.05)^{2}} \\
& =\quad \frac{550}{1+550(0.0025)} \\
& =\quad \frac{550}{1+0.025} \\
& =\frac{550}{1.38} \\
& \begin{array}{ll}
=\quad 398.5 \\
\end{array} \\
& =\quad \approx 399
\end{aligned}
$$

\section{Sources of data collection and data collection method}

The researcher will use the primary and secondary method of gathering data for this research study. The primary research data will be generated basically through a structured questionnaire which would be administered to respondents while the secondary research data will be obtained from articles, journals, annual reports, textbooks, etc.

\section{Research instrument}

Questionnaire instrument will be used in gathering data from the respondents or customers. It will be structured in simple English. 
Journal DOI: 10.46654/ij.24889849

\section{Validity and reliability of instrument}

According to Asika (2004), it refers to the degree to which a measuring instrument measure what it is designed to measure. Two levels of validity will be carried out. First, the questionnaire will pass through face validity; checked by supervisor for criticism and recommendation. Secondly, a pre-test using a sample comprising workers will be carried out.

Reliability of the instrument will be measured through the test-retest method. This has to do with consistency.

\section{Data analyses technique}

The statistical tool to be used in testing the hypotheses is the Chi-square which is often denoted by $\mathrm{x}^{2}$. The $\mathrm{x}^{2}$ test helps to test as to whether or not the test of observed frequencies differs significantly from the expected one.

The formular for calculating the Chi-square is given below as:

$$
x^{2}=\sum \frac{(\text { fo }-f e)^{2}}{f e}
$$

Where;

$$
\begin{array}{lll}
\mathrm{x}^{2} & = & \text { Chi-square } \\
\text { fe } & = & \text { expected frequency } \\
\text { fo } & = & \text { observed frequency } \\
\sum & = & \text { summation }
\end{array}
$$

The observed frequency (o) is that obtained after an observation or experiment has been carried or data collected from the field. The expected frequencies are generated on the basis of a hypothesis or speculation.

The test for significance of this study at 0.05 level of significant would be used with the aid of degree of freedom (df). Degree of freedom refers to the independent prices of information the researcher can use in sample. The formular is thus, calculated as:

$$
\mathrm{df}=(\mathrm{r}-1)(\mathrm{c}-1)
$$

Where;

$\begin{array}{lll}\mathrm{r} & = & \text { the number of rows } \\ \mathrm{c} & = & \text { the number of columns } \\ 1 & = & \text { a constant } \\ \mathrm{df} & = & \text { degree of freedom }\end{array}$

\section{Decision rule}

Before we decide on whether or not the response frequencies among the series are significant, there is a rule of the thumb we need to recite. If the critical value under the relevant level of significance is greater than our calculated or obtained value of $x^{2}$, then the difference is not significant at the particular level. 


\subsection{DATA PRESENTATION, ANALYSES AND DISCUSSION OF FINDINGS}

This section deals primarily with various responses obtained from questionnaire. It served as the sources of background data for this research.

Also, for this research, a total number of three hundred and ninety-nine (399) copies of questionnaire were issued. And a total of one hundred and fifty (150) copies of questionnaire were completed and returned to the researcher.

\section{Data presentation}

From table 4.1.1, 98 respondents representing 65.30 percent were male, while 52 respondents representing 34.70 percent were female.

Table 4.1.2 shows that, 21 respondents representing 14.00 percent were 18-25 years, 41 respondents representing 27.30 percent were 26-35 years, 46 respondents representing 30.70 percent were $36-45$ years, while 42 respondents representing 28.00 were 46 years above.

From table 4.1.3, 86 respondents representing 57.30 percent were single, 55 respondents representing 36.70 percent were married while 9 respondents representing 6.00 were divorced.

Table 4.1.4 indicates that, 20 respondents representing 13.30 percent were FSLC holders, 37 respondents representing 24.70 percent were WAEC holders while 93 respondents representing 62.00 were HND/B.Sc. holders.

TABLE 4.1.1

Distribution of respondents according to sex

\begin{tabular}{lcc}
\hline Sex & Number of respondents & Percentage \\
\hline Male & 98 & 65.30 \\
Female & 52 & 34.70 \\
Total & 150 & 100.00 \\
\hline
\end{tabular}

Source: Survey work, 2020.

TABLE 4.1.2

Distribution of respondents according to age

\begin{tabular}{lcc}
\hline Age & Number of respondents & Percentage \\
\hline $18-25$ years & 21 & 14.00 \\
26-35 years & 41 & 27.30 \\
36-45 years & 46 & 30.70 \\
36 years above & 42 & 28.00 \\
Total & 150 & 100.00 \\
\hline
\end{tabular}

Source: Survey work, 2020. 
TABLE 4.1.3

Distribution of respondents according to marital status

\begin{tabular}{lcc}
\hline Marital status & Number of respondents & Percentage \\
\hline Single & 86 & 57.30 \\
Married & 55 & 36.70 \\
Divorced & 9 & 6.00 \\
Total & 150 & 100.00 \\
\hline
\end{tabular}

Source: Survey work, 2020.

TABLE 4.1.4

Distribution of respondents according to educational qualification

\begin{tabular}{lcc}
\hline $\begin{array}{l}\text { Educational } \\
\text { qualification }\end{array}$ & Number of respondents & Percentage \\
\hline FSLC & 20 & 13.30 \\
WAEC & 37 & 24.70 \\
HND/B.Sc. & 93 & 62.00 \\
Total & 150 & 100.00 \\
\hline
\end{tabular}

Source: Survey work, 2020.

\subsection{Data analyses and interpretation}

TABLE 4.2.1

Branding positively affects consumer behaviour

\begin{tabular}{lcc}
\hline Responses & $\begin{array}{c}\text { Number of } \\
\text { respondents }\end{array}$ & Percentage \\
\hline Strongly Agree & 108 & 72.00 \\
Agree & 19 & 12.70 \\
Disagree & 6 & 4.00 \\
Strongly disagree & 5 & 3.30 \\
Undecided & 12 & 8.00 \\
Total & 150 & 100.00 \\
\hline
\end{tabular}

Source: Survey work, 2020.

From the above table 4.2.1, 108 respondents representing 72.00 percent strongly agree, 19 respondents representing 12.70 percent agree, 6 respondents representing 4.00 percent disagree, 5 respondents representing 3.30 percent strongly disagree while 12 respondents representing 8.00 percent were undecided.

From table 4.2.2, 58 respondents representing 38.70 percent strongly agree, 67 respondents representing 44.60 percent agree, 10 respondents representing 4.00 percent disagree, 
6 respondents representing 2.40 percent strongly disagree while 9 respondents representing 3.60 percent were undecided.

Table 4.2.3 shows that, 55 respondents representing 36.70 percent strongly agree, 19 respondents representing 30.70 percent agree, 29 respondents representing 19.30 percent disagree, 12 respondents representing 8.00 percent strongly disagree; while 8 respondents representing 5.30 percent were undecided.

From table 4.2.4, 40 respondents representing 26.70 percent strongly agree, 60 respondents representing 40.00 percent agree, 15 respondents representing 10.00 percent disagree, 30 respondents representing 20.00 percent strongly disagree while 8 respondents representing 3.30 percent were undecided.

From table 4.2.5, 63 respondents representing 42.00 percent strongly agree, 40 respondents representing 26.70 percent agree, 19 respondents representing 12.60 percent disagree, 18 respondents representing

TABLE 4.2.2

Non branded information has negative impact on consumer choice

\begin{tabular}{lcc}
\hline Responses & $\begin{array}{c}\text { Number of } \\
\text { respondents }\end{array}$ & Percentage \\
\hline Strongly Agree & 58 & 38.70 \\
Agree & 67 & 44.60 \\
Disagree & 10 & 4.00 \\
Strongly disagree & 6 & 2.40 \\
Undecided & 9 & 3.60 \\
Total & 150 & 100.00 \\
\hline
\end{tabular}

Source: Survey work, 2020.

TABLE 4.2.3

Is there any effect of branding on consumer behaviour?

\begin{tabular}{lcc}
\hline Responses & $\begin{array}{c}\text { Number of } \\
\text { respondents }\end{array}$ & Percentage \\
\hline Strongly Agree & 55 & 36.70 \\
Agree & 46 & 30.70 \\
Disagree & 29 & 19.30 \\
Strongly disagree & 12 & 8.00 \\
Undecided & 8 & 5.30 \\
Total & 150 & 100.00 \\
\hline
\end{tabular}

Source: Survey work, 2020. 
TABLE 4.2.4

Branding leads to consumer perception bias

\begin{tabular}{lcc}
\hline Responses & Number of respondents & Percentage \\
\hline Strongly Agree & 40 & 26.70 \\
Agree & 60 & 40.00 \\
Disagree & 15 & 10.00 \\
Strongly disagree & 30 & 20.00 \\
Undecided & 5 & 3.30 \\
Total & 150 & 100.00 \\
\hline Soul
\end{tabular}

Source: Survey work, 2020.

TABLE 4.2.5

Brand distinguishes other products

\begin{tabular}{lcc}
\hline Responses & Number of respondents & Percentage \\
\hline Strongly Agree & 63 & 42.00 \\
Agree & 40 & 26.70 \\
Disagree & 19 & 12.60 \\
Strongly disagree & 18 & 12.00 \\
Undecided & 10 & 6.70 \\
Total & 150 & 100.00 \\
\hline Sol
\end{tabular}

Source: Survey work, 2020

12.00 percent strongly disagree while 10 respondents representing 6.70 percent were undecided.

From the table 4.2.6, 10 respondents representing 6.70 percent strongly agree, 18 respondents representing 12.00 percent agree, 19 respondents representing 12.60 percent disagree, 40 respondents representing 26.70 percent strongly disagree while 63 respondents representing 42.00 percent were undecided.

From the table 4.2.7, 108 respondents representing 72.70 percent strongly agree, 19 respondents representing 12.70 percent agree, 6 respondents representing 4.00 percent disagree, 5 respondents representing 3.30 percent strongly disagree while 12 respondents representing 8.00 percent were undecided.

From the table 4.2.8, 58 respondents representing 38.70 percent strongly agree, 67 respondents representing 44.60 percent agree, 10 respondents representing 4.00 percent disagree, 6 respondents representing 2.40 percent strongly disagree while 9 respondents representing 3.60 percent were undecided. 
From the table 4.2.9, 55 respondents representing 36.70 percent strongly agree, 46 respondents representing 30.70 percent agree, 29 respondents representing 19.30 percent disagree, 12 respondents representing 8.00 percent strongly disagree while 8 respondents representing 5.30 percent were undecided.

TABLE 4.2.6

Proper branding results in higher sales

\begin{tabular}{lcc}
\hline Responses & Number of respondents & Percentage \\
\hline Strongly Agree & 10 & 6.70 \\
Agree & 18 & 12.00 \\
Disagree & 19 & 12.60 \\
Strongly disagree & 40 & 26.70 \\
Undecided & 63 & 42.00 \\
Total & 150 & 100.00 \\
\hline Soure: Survey
\end{tabular}

Source: Survey work, 2020.

TABLE 4.2.7

Branding is the most efficient way to show potential customers what your business is about

\begin{tabular}{lcc}
\hline Responses & Number of respondents & Percentage \\
\hline Strongly Agree & 108 & 72.00 \\
Agree & 19 & 12.70 \\
Disagree & 6 & 4.00 \\
Strongly disagree & 5 & 3.30 \\
Undecided & 12 & 8.00 \\
Total & 150 & 100.00 \\
\hline
\end{tabular}

Source: Survey work, 2020.

TABLE 4.2.8

Good branding increases the value of the product and the company

\begin{tabular}{lcc}
\hline Responses & Number of respondents & Percentage \\
\hline Strongly Agree & 58 & 38.70 \\
Agree & 67 & 44.60 \\
Disagree & 10 & 4.00 \\
Strongly disagree & 6 & 2.40 \\
Undecided & 9 & 3.60 \\
Total & 150 & 100.00 \\
\hline
\end{tabular}

Source: Survey work, 2020. 
TABLE 4.2.9

Cultural factors influence consumer behaviour

\begin{tabular}{lcc}
\hline Responses & Number of respondents & Percentage \\
\hline Strongly Agree & 55 & 36.70 \\
Agree & 46 & 30.70 \\
Disagree & 29 & 19.30 \\
Strongly disagree & 12 & 8.00 \\
Undecided & 8 & 5.30 \\
Total & 150 & 100.00 \\
\hline Soure: Survey
\end{tabular}

Source: Survey work, 2020.

From the table $4.2 .10,40$ respondents representing 26.70 percent strongly agree, 60 respondents representing 40.00 percent agree, 15 respondents representing 10.00 percent disagree, 30 respondents representing 20.00 percent strongly disagree while 5 respondents representing 3.30 percent were undecided.

From the table 4.2.11, 63 respondents representing 42.00 percent strongly agree, 40 respondents representing 26.70 percent agree, 19 respondents representing 12.60 percent disagree, 18 respondents representing 12.00 percent strongly disagree while 10 respondents representing 6.70 percent were undecided.

\subsection{Test of hypothesis}

The Chi-square $\left(\mathrm{X}^{2}\right)$ is the statistical tool which is used to test the reliability of the research whether it is accepted or rejected.

\section{Decision rule}

If $\mathrm{X}_{\mathrm{O}}^{2}<\mathrm{X}_{\mathrm{t}}^{2}$, the researcher has the option to accept the null hypothesis (Ho) and reject the alternative hypothesis $(\mathrm{H} 1)$ and if $\mathrm{X}_{\mathrm{O}}^{2}>\mathrm{X}_{\mathrm{t}}^{2}$, the option is to accept the alternative hypothesis (H1) and reject the null hypothesis (Ho).

The hypothesis will be tested at 5 percent level of significance (the desired level of significance is $\alpha .5)$. This is done through establishing the significance level and identification of acceptance and rejection hypothesis. 
TABLE 4.2.10

Personal factors like age and way of life affect consumer behaviour

\begin{tabular}{lcc}
\hline Responses & Number of respondents & Percentage \\
\hline Strongly Agree & 40 & 26.70 \\
Agree & 60 & 40.00 \\
Disagree & 15 & 10.00 \\
Strongly disagree & 30 & 20.00 \\
Undecided & 5 & 3.30 \\
Total & 150 & 100.00 \\
\hline
\end{tabular}

Source: Survey work, 2020.

TABLE 4.2.11

Consumer products maximize profit and market share

\begin{tabular}{lcc}
\hline Responses & Number of respondents & Percentage \\
\hline Strongly Agree & 63 & 42.00 \\
Agree & 40 & 26.70 \\
Disagree & 19 & 12.60 \\
Strongly disagree & 18 & 12.00 \\
Undecided & 10 & 6.70 \\
Total & 150 & 100.00 \\
\hline
\end{tabular}

Source: Survey work, 2020.

TABLE 4.3.1

Hypothesis 1: There is no significant relationship between reduced branding and consumer behaviour

\begin{tabular}{|c|c|c|c|c|c|}
\hline Items & o & $\mathrm{e}$ & (o-e) & $(o-e)^{2}$ & $\frac{(\mathrm{o}-\mathrm{e})^{2}}{\mathrm{E}}$ \\
\hline $\mathrm{SA}$ & 108 & 30 & 78 & 6084 & 202.8 \\
\hline A & 19 & 30 & -11 & 121 & 4.03 \\
\hline $\mathrm{D}$ & 6 & 30 & -24 & 576 & 19.2 \\
\hline SD & 5 & 30 & -25 & 625 & 20.8 \\
\hline $\mathrm{U}$ & 12 & 30 & -18 & 324 & 10.8 \\
\hline Total & 150 & 150 & 0 & 7730 & 257.63 \\
\hline \multirow{2}{*}{\multicolumn{2}{|c|}{$\begin{array}{l}\text { Calculated value } \\
\text { Degree of freedom }\end{array}$}} & $=$ & 257.63 & & \\
\hline & & $=$ & $\mathrm{n}-1$ & & \\
\hline & & $=$ & $5-1$ & & \\
\hline & & $=$ & 4 & & \\
\hline \multicolumn{2}{|c|}{ Critical value of 0.05 at $4 \mathrm{df}$} & $=$ & 9.49. & & \\
\hline
\end{tabular}




\section{Interpretation}

From the $\mathrm{X}^{2}$ analysis of $\mathrm{H}_{1}$, the calculated value is 257.63 while the critical value is 9.49 . The $X^{2}$ rule states that since the calculated value (257.63) is greater than critical value (9.49), it is therefore concluded that alternate hypothesis is upheld and null hypothesis is rejected. The analysis revealed that there is a significant relationship between reduced branding and consumer behaviour.

\section{Interpretation}

From the $\mathrm{X}^{2}$ analysis of $\mathrm{H}_{1}$, the calculated value is 61.79 while the critical value is 9.49 . The $\mathrm{X}^{2}$ rule states that since the calculated value (61.79) is greater than critical value (9.49), it is therefore concluded that alternate hypothesis is upheld and null hypothesis is rejected. The analysis revealed that there is a significant relationship between non-branding information and consumer choice.

\section{Interpretation}

From the $\mathrm{X}^{2}$ analysis of $\mathrm{H}_{1}$, the calculated value is 118.99 while the critical value is 9.49 . The $X^{2}$ rule states that since the calculated value (118.99) is greater than critical value (9.49), it is therefore concluded that alternate hypothesis is upheld and null hypothesis is rejected. The analysis revealed that there is a significant relationship between copycat branding and consumer behaviour.

\section{TABLE 4.3.2}

Hypothesis 2: There is no significant relationship between non-branding information and consumer choice

\begin{tabular}{|c|c|c|c|c|c|}
\hline Items & o & $\mathrm{e}$ & (o-e) & $(0-e)^{2}$ & $\frac{(\mathrm{o}-\mathrm{e})^{2}}{\mathrm{E}}$ \\
\hline SA & 10 & 30 & -20 & 400 & 13.33 \\
\hline A & 18 & 30 & -12 & 144 & 4.8 \\
\hline D & 19 & 30 & -11 & 121 & 4.03 \\
\hline SD & 40 & 30 & 10 & 100 & 3.33 \\
\hline $\mathrm{U}$ & 63 & 30 & 33 & 1089 & 36.3 \\
\hline Total & 150 & 150 & 0 & 1854 & 61.79 \\
\hline \multicolumn{2}{|c|}{ Calculated value } & $=$ & 61.79 & & \\
\hline \multirow{3}{*}{\multicolumn{2}{|c|}{ Degree of freedom }} & $=$ & $\mathrm{n}-1$ & & \\
\hline & & $=$ & $5-1$ & & \\
\hline & & $=$ & 4 & & \\
\hline Critica & 05 at $4 \mathrm{df}$ & $=$ & 9.49 . & & \\
\hline
\end{tabular}


TABLE 4.3 .3

Hypothesis 3: There is no significant relationship between copycat branding and consumer behaviour

\begin{tabular}{|c|c|c|c|c|c|}
\hline Items & o & e & (o-e) & $(0-e)^{2}$ & $\frac{(\mathrm{o}-\mathrm{e})^{2}}{\mathrm{e}}$ \\
\hline SA & 58 & 30 & 28 & 784 & 26.13 \\
\hline A & 67 & 30 & 37 & 1369 & 45.63 \\
\hline D & 10 & 30 & -20 & 400 & 13.33 \\
\hline SD & 6 & 30 & -24 & 576 & 19.2 \\
\hline $\mathrm{U}$ & 9 & 30 & -21 & 441 & 14.7 \\
\hline Total & 150 & 150 & 0 & 3570 & 118.99 \\
\hline \multirow{2}{*}{\multicolumn{2}{|c|}{$\begin{array}{l}\text { Calculated value } \\
\text { Degree of freedom }\end{array}$}} & $=$ & 118.99 & & \\
\hline & & $=$ & $\mathrm{n}-1$ & & \\
\hline & & $=$ & $5-1$ & & \\
\hline & & $=$ & 4 & & \\
\hline Critic & 05 at $4 \mathrm{df}$ & $=$ & 9.49 . & & \\
\hline
\end{tabular}

TABLE 4.3.4

Hypothesis 4: There is no significant relationship between branding and consumer perception

\begin{tabular}{lccccc}
\multicolumn{5}{c}{ bias } \\
\hline Items & $\mathrm{o}$ & $\mathrm{e}$ & $(\mathrm{o}-\mathrm{e})$ & $(\mathrm{o}-\mathrm{e})^{2}$ & $\frac{(\mathrm{o}-\mathrm{e})^{2}}{\mathrm{e}}$ \\
\hline $\mathrm{SA}$ & 40 & 30 & 10 & 100 & 3.33 \\
$\mathrm{~A}$ & 60 & 30 & 30 & 900 & 30 \\
$\mathrm{D}$ & 15 & 30 & -15 & 225 & 7.5 \\
$\mathrm{SD}$ & 30 & 30 & -0 & 0 & 0 \\
$\mathrm{U}$ & 5 & 30 & -15 & 225 & 7.5 \\
Total & 150 & 150 & 0 & 1450 & 48.33 \\
\hline
\end{tabular}

Calculated value

$\begin{array}{ll}= & 48.33 \\ = & \mathrm{n}-1 \\ = & 5-1 \\ = & 4 \\ = & 9.49 .\end{array}$

Critical value of 0.05 at $4 \mathrm{df}$

$$
=9.49 \text {. }
$$

\section{Interpretation}

From the $\mathrm{X}^{2}$ analysis of $\mathrm{H}_{1}$, the calculated value is 48.33 while the critical value is 9.49 . The $X^{2}$ rule states that since the calculated value (48.33) is greater than critical value (9.49), it is 
therefore concluded that alternate hypothesis is upheld and null hypothesis is rejected. The analysis revealed that there is a significant relationship between branding and consumer perception bias.

\subsection{Discussion of findings}

Based on the analysis of the result, the following hypotheses were revealed:

In hypothesis one, it was revealed that, there is a significant relationship between reduced branding and consumer behaviour. The study conforms to the works of Aaker (1991) who posit that branding is the process of creating and disseminating the brand name.

In hypothesis two, it was shown that there is a significant relationship between nonbranding information and consumer choice.

In hypothesis three, it was revealed that there is a significant relationship between copycat branding and consumer behaviour.

In hypothesis four, it was shown that there is a significant relationship between branding and consumer perception bias. The findings of these hypotheses conform to the works of Arnold (2007), Aaker (2004), Founiew (2004), Brasel (2004) who postulated that proper branding can result in higher sales and branding is the most efficient way to show potential customers what your business is about.

\section{Summary of findings}

The major findings are made:

1. There is no significant relationship between reduced branding and consumer behaviour.

2. There is a significant relationship between non-branding information and consumer choice.

3. There is a significant relationship between copycat branding and consumer perception bias.

\subsection{Conclusion}

The study portrays the effect of branding on consumer behaviour of selected petroleum products in Rivers State. Consumer behaviour occurs when consumers are stimulated by external factors and come to a purchase decision based on their personal characteristics and decision making process. Through branding, consumers are able to recognize a product, evaluate its quality and obtain certain experience and satisfaction out of product differentiation. Branding is the process of creating and disseminating the brand name. It can be applied to the entire corporate identity as well as to individual product and service names. It is concluded that, branding affects consumer behaviour and proper branding results in higher sales. 
International Journal of Advanced Academic Research (Business and Economic Development) | ISSN: 2488-9849

Journal DOI: 10.46654/ij.24889849

Vol. 6, Issue 11 (November, 2020) | www.ijaar.org

Article DOI: 10.46654/ij.24889849.b61122

\section{Recommendations}

The following recommendations are proffered:

1. Management should embark on building brand images in way of influencing consumer behaviours.

2. Corporations should focus on market research in order to improve the performance of the company.

3. Management should implement appropriate policies which lead to business success. 


\section{REFERENCES}

Aaker, D. A. (1991). Building strong brands. Brandweek, 3(6), 28-34.

Aaker, J. L., Founiew, S. \&Brasel, S. A. (2004). When good brands do bad. Journal of Consumer Research, 31, 1-17.

Alexander, S. (2008). Fords owns brand loyalty in 2007. www.autoblog.com/2009

Arnold, E. (2007). Animating the big middle. Journal of Retailing, 81, 89-96.

Botton, L. E., Warlop, L. \& Alba, J. W. (2003). Consumer perception of price. Journal of Consumer Research, 29(4), 474-491.

Cove, V. \& Remy, E. (2007). I feel good - who needs the market. Struggling and having fun with consumer driven experiences. In A. Caru and Cava (es) consuming experience. New York: Routledge, 17-33.

Dixon, U. (2005). Managing brand equity, capitalizing on the value of a brand name. New York: Free Press.

Dwayne, A. M. (2005). Creating and managing brands. Journal of marketing, 2(2), 74-102.

Fraji, E. \& Martinez, E. (2007). Ecological consumer behaviour. International Journal of Consumer Studies, 31(1), 26-33.

Grewal, U., Krishna, V. \& Born (1998). A survey-based method for measuring and understanding brand equity and its extendibility. Journal of Marketing Research, 3(1), 271-288.

Hatch, M. J. \& Schultz, M. (2003). Are the strategies stars ak-aligred for your corporate brand.Harvard Business Review, 79, 128-134.

Kapferer, J. N. (2004). The new strategies brand management. London: Kogan Publishers.

Keller, K. L. (2003). Brand synthesis: The multidimensionality of brand knowledge. Journal of Consumer Research, 29(4), 595-600.

Kotler, P. (1991). Marketing management. Englewood Cliffs, New Jersey: Prentice Hall. 
International Journal of Advanced Academic Research (Business and Economic Development) | ISSN: 2488-9849

Journal DOI: 10.46654/ij.24889849

Vol. 6, Issue 11 (November, 2020) | www.ijaar.org

Article DOI: 10.46654/ij.24889849.b61122

Leitch, S. \& Richardson, N. (2003). Corporate branding in the new economy. European Journal of Marketing, 37, 1065-1079.

Li, X. (2009). Loyalty regardless of brands. Examining three non-performance effects on brand loyalty in a tourism context. Journal of Travel Research, 49(3), 323-336.

Loudon, I. \&Bitta, K. (1998). What do you know about customer perceived quality? Marketing Science, 18(1), 20-31. 